\title{
Analisa Lahan Kritis Sub DAS Riam Kanan DAS Barito Kabupaten Banjar Kalimantan Tengah
}

\author{
Sismanto \\ Staf pengajar Program Studi Diploma Teknik Sipil FTSP ITS \\ Email : sismantosis@ce.its.ac.id
}

\begin{abstract}
ABSTRAK
Fenomena kejadian banjir, tanah Iongsor, dan kekeringan serta pencemaran kualitas air beberapa tahun terakhir menunjukkan peningkatan pada sub Das Riam Kanan kabupaten banjar, merupakan indikasi adanya kerusakan Iahan. Upaya Konservasi DAS harus dilakukan tetapi timbul pertanyaan dari mana upaya tersebut harus dimulai. Tulisan ini dimaksudkan untuk menjawab pertanyaan tersebut, cara yang dilakukan adalah dengan mengintepretasi peta citra Aster, mengalisa tingkat erosi, dan mengklasifikasi lahan kritis. Hasil yang diperoleh dari analisa ini menunjukkan bahwa 43\% Sub DAS Riam Kanan merupakan lahan kritis dengan erosi total 150,93 ton/ $\mathrm{Ha} /$ tahun. Untuk mengembalikan pada fungsi DAS semula perlu tahapan upaya konservasi, 30\% harus dilakukan dalam jangka pendek, 32\% harus dilakukan pada jangka menengah dan sisanya bisa dilakukan pada jangka panjang.
\end{abstract}

\section{Kata kunci : DAS Barito, Sub DAS Riam Kanan, Erosi, lahan kritis}

\section{PENDAHULUAN.}

Sub DAS Riam Kanan merupakan salah satu bagian dari DAS Barito Kabupaten Banjar Kalimantan Selatan. Fenomena kejadian banjir, tanah longsor, dan kekeringan serta pencemaran kualitas air beberapa tahun terakhir menunjukkan peningkatan, hal ini mengindikasikan telah terjadi gangguan keseimbangan siklus hidrologi didaerah aliran sungai. Untuk itu, maka pada pada tanggal 28 April 2005 Pesiden RI mencanangkan Gerakan Nasional Kemitraan Penyelamatan Air (GN-KPA) yang bertuj uan untuk mengembalikan keseimbangan siklus hidrologi pada DAS sehingga keandalan sumber-sumber air baik kuantitas maupun kualitas airnya dapat terkendali.

Agar GNKPA dapat berjalan sesuai dengan harapan semua pihak maka upaya konservasi DAS harus diawali dengan penetapan daerah kritis yang nantinya digunakan sebagai acuan untuk penetapan daerah daerah prioritas.

Maksud dari kajian ini adalah untuk menetapkan daerah daerah kritis yang nantinya dapat digunakan sebagai dasar perencanaan dalam upaya memulihkan, mempertahankan, dan meningkatkan fungsi Sub DAS sebagai ekosistim alam yang berperan dalam pengaturan siklus hidrologis. Kekritisan lahan pada suatu DAS merupakan suatu kondisi yang ditunjukkan oleh rendahnya kesuburan tanah karena lapisan tanah atas (top soil) telah hilang, lapisan ini sebagai media bagi micro flora dan micro fauna. Hilangnya lapisan tanah atas sebagian besar disebabkan oleh erosi, sehingga untuk melihat kekritisan suatu lahan dapat pula ditunjukkan oleh besarnya erosi yang terjadi.

\section{RUMUSAN MASALAH}

Sub DAS Riam Kanan telah diindikasikan sebagai DAS Kritis yang perlu penanganan konservasi, untuk upaya itu perlu diketahui terlebih dahulu hal hal sebagai berikut:

a. Berapa besar erosi yang terjadi

b. wilayah bagian mana saja yang perlu mendapatkan penanganan konservasi pada jangka pendek, mengengah, dan jangka panjang.

\section{METODOLOGI}

\subsection{Interpretasi foto satelit}

Secara umum metodologi yang digunakan untuk menjawab permasalahan tersebut adalah dengan langkah langkah sebagai berikut :

a. Pengumpulan data sekunder yang diambil instansi instansi terkait dan dari 
studi studi terdahulu, dilanjutkan dengan orientasi lapangan.

b. Pengadaan dan Analisa peta Citra Satelite dengan menggunakan aplikasi Arc View.

c. Analisa dan perhitungan Erosi Lahan.

d. Penetapan dan rangking prioritas daerah Kritis.

Kegiatan pengumpulan data dibagi dalam 2 tahap, yaitu : (1) pengumpulan data awal dan (2) pengumpulan data lanjutan. Pengumpulan data awal dilakukan untuk mendapatkan gambaran awal tentang kondisi DAS. Secara umum data yang diperlukan dalam pekerjaan ini adalah :

- peta rupa bumi,

- data curah hujan,

- peta geologi,

- Data/Peta Tata Guna Lahan

Citra Satelit adalah suatu gambar rekaman kondisi permukaan bumi yang di ambil dari sensor yang dibawa oleh satelit. Orbit satelit ini berada diluar angkasa $\pm 950 \mathrm{~km}$ dari permukaan bumi dan dapat merekam kembali setiap $16 \mathrm{~km}$ untuk daerah yang sama.

Umumnya citra satelit yang digunakan untuk mendukung studi adalah jenis citra satelit TM (Thematic Mapper). Akan tetapi mulai tahun 2004 citra satelit TM tidak dapat diadakan, sebagai penggantinya mulai tahun 2005 telah diorbitkan citra satelit TERRA ASTER dengan spesifikasi sebagai berikut,

J enis Citra :TERRA ASTER

J enis Data : Data Digital dan Hard Copy

Path / Row : :118/66

Tahun : 2008

Band $\quad: 1,2,3,4,5,6,7,8$ dan 9

Resolusi $\quad: 15 \mathrm{~m} \mathrm{~s} / \mathrm{d} 30 \mathrm{~m}$

Liputan awan : $\max 10 \%$

Analisa Citra satelit dilakukan dengan cara interpretasi foto satelit yang dimassudkan untuk :

- Penetapan luas tutupan Iahan

- Penetapan luas lahan kritis

- Penetapan kemiringan lereng

- Penetapan bentuk lahan (land form)

- Identifikasi sumber-sumber air

\subsubsection{Penetapan luas tutupan lahan}

Luas tutupan lahan pada DAS di interpretasikan dengan cara:

1. Menyiapkan citra satelit dalam bentuk hard copy skala $1: 250.000$.

2. Melakukan delineasi objek tutupan lahan secara visual dengan bentuan alat loupe (kaca pembesar).

3. Melakukan cross check dengan kunci interpretasi (sampel interpretasi yang diperoleh de lapangan) guna perbaikan delineasi tutupan lahan.

4. hasil delineasi tutupan lahan tersebut ditransfer / dipindah kedalam peta dasar yang diperoleh dari Peta Rupa Bumi skala 1 : 25.000 dengan metode adjusment / penyesuaian.

5. Kemudian diatas peta skala $1: 25.000$ tersebut dilakukan perhitungan luasnya dengan bantuan alat planimeter.

\subsubsection{Penetapan luas lahan kritis}

Fenomena untuk penetapan lahan kritis sebagaimana dijelaskan dalam pendekatan studi tersebut dimuka adalah bahwa lahan kritis ditentukan dari paduan beberapa faktor antara lain Topografi, Intensitas hujan, Penutup Iahan, Kepekaan Iahan, dan Budaya manusia

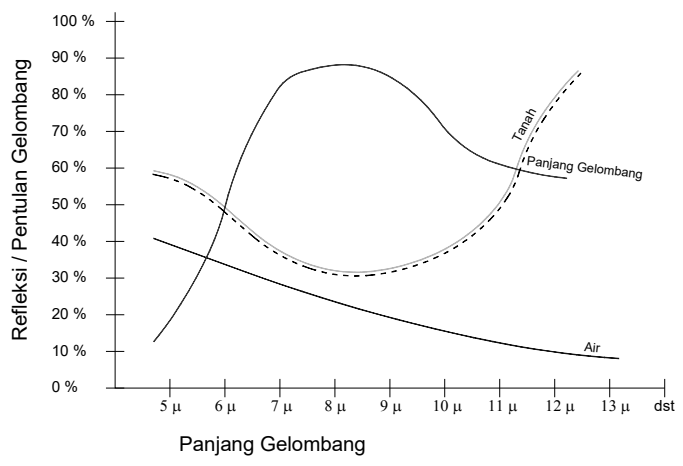

Grafik Karakteristik Spektrum Band Citra Terra Aster

Guna menginterpretasikan luas lahan kritis antara lain caranya sebagai berikut :

1. Menyiapkan citra satelit dalam bentuk hard copy skala $1: 250.000$

2. Disamping sitra satelit tersebut juga disiapkan :

- Peta RBI skala $1: 25.000$

- Peta tanah skala $1: 50.000$ 
- Peta isohyet atau peta poligon Theissen

3. Kemudian dilakukan klarifikasi data topografi yang diwakili oleh besarnya kemiringan lereng.

Disamping itu data tanah juga di klarifikasikan menurut LPT Dep. Pertanian sebagai berikut :

- Tanah aluvial, glei, planosol Hidromorf kelabu, lateril diklarifikasikan tidak peka terhadap erosi

- Latosol diklarifikasikan agak peka terhadap erosi

- Brown Forest Soil, Non Classic Brown, Mediteran diklarifikasikan kurang peka terhadap erosi

- Andosol, laterit, grumusol, podsol dan podsolid diklarifikasikan peka terhadap erosi.

- Regosol, litosol, organosol, rluzina diklarifikasikan peka terhadap erosim.

- Data intensitas hujan ( $\mathrm{mm} /$ hari) diklarifikasikan sebagai berikut :

$\begin{array}{llll}0 & 0-13,6 & : & \text { sangat rendah } \\ 0 & 13,6-20,7: & \text { rendah } \\ 0 & 20,7-27,7: & \text { sedang } \\ 0 & 27,7-34,8: & \text { tinggi } \\ 0 & >34,8 \%: & \text { sangat tinggi }\end{array}$

4. Hasil klarifikasi data faktor tersebut diatas (topografi, intensitas hujan, penutup lahan, kepekaan tanah dan budaya manusia) dalam hal ini digunakan untuk membantu delineasi klasifikasi masing-masing faktor tersebut pada citra satelit aster dengan prinsip sebagai berikut

- Makin curam topografinya, klasifikasinya semakin kritis lahannya

- Makin besar intensitas curah hujannya klasifikasinya semakin kritis

- Semakin terang vegetasi penutup lahannya (kecuali sawah-sawah dan pemukiman) semakin besar tingkat kekritisan lahannya.
- Semakin peka jenis tanahnya, klasifikasinya semakin besar tingkat kekritisan lahannya.

- Semakin padat penduduknya, klasifikasinya semakin besar tingkat kekritisan lahannya.

5. Dari delineasi klasifikasi masing-masing faktor kemudian di super impose untuk mendapatkan sub delineasi. Tingkat kekritisan Iahan dalam hal ini klasifikasi lahan kritis dibedakan dengan :

- Erosi asngat berat

- Erosi berat

- Erosi sedang

- Erosi ringan

- Hampir tidak ada erosi

6. Kemudian data klasifikasi Iahan kritis ini ditranfer kedalam peta dasar RBI skala 1 : 25.000 akan diperoleh peta lahan kritis.

7. Dari peta lahan kritis tersebut masingmasing klasifikasi dihitung luasnya dengan alat planimeter, sehingga akan mendapatkan angka luas lahan kritis secara akurat karena peta RBI telah mempunyai angka koordinat yang bergeoreferensi.

\subsubsection{Penetapan kemiringan lereng}

Cara interpretasi kemiringan lereng pada citra satelit Aster dalam hal ini kadang harus berbenturan dengan data peta RBI skala 1 : 25.000. Pada prinsipnya kemiringan lereng dapat dihitung dari kerapatan kontur pada peta RBI. Semakin rapat garis konturnya disini dapat diasumsikan semakin curam lerengnya.

Klasifikasi lereng yang telah diutarakan tersebut didasarkan pada asumsi :

$\begin{array}{lll}\text { Tg } & \alpha & =1 \\ & \alpha & =45^{\circ} \\ \text { Slope } & & =100 \%\end{array}$

\subsubsection{Penetapan bentuk lereng}

Cara interpretasi citra satelit Terra Aster untuk mengetahui penyebaran bentuk lahan (land form) yaitu dengan :

- Melihat kenampakan tiga dimensi pada peta

- Membedakan pola aliran sungai dan bentuk percabangan anak-anak sungainya 
- Berbatuan dengan peta kemiringan lereng yang telah dibuat

Kemudian hasil delineasi land form pada citra satelit ditransfer kedalam peta dasar RBI dan seterusnya dihitung luasnya dengan planimeter.

\subsection{Analisa Erosi Lahan}

Untuk mengetahui tingkat kekritisan suatu DAS, salah satu indikatornya adalah besarnya erosi yang terjadi pada DAS tersebut. Dari sekian banyak rumusan yang dapat dipergunakan untuk memprediksi besarnya erosi, model yang dikembangkan oleh Wischmeier dan Smith (1978) yang biasa dikenal dengan the Universal Soil Loss Equation (USLE) merupakan metode yang paling populer dan banyak digunakan untuk memprediksi besarnya erosi. USLE adalah suatu model erosi yang dirancang untuk memprediksi rata-rata erosi jangka panjang dari erosi lembar (sheet erosion) termasuk di dalamnya erosi alur (rill erosion) pada suatu keadaan tertentu. Erosi yang terjadi selanjutnya dihitung pada masing-masing unit lahan, dilajutkan dengan perhitungan laju rata-rata erosi dari suatu bidang tanah tertentu.

Persamaan yang dipergunakan mengelompokkan berbagai parameter fisik (dan pengelolaan) yang mempengaruhi laju erosi ke dalam enam parameter utama. Persamaan USLE yang diusulkan adalah sebagai berikut:

\section{$A=R K L S C P$}

dimana:

$\mathrm{A}=$ adalah banyaknya tanah yang tererosi dalam [ton per hektar per tahun].

$\mathrm{R}=$ adalah faktor curah huj an dan aliran permukaaan (erosivitas hujan), yaitu jumlah satuan indeks erosi hujan.

$\mathrm{K}=$ adalah faktor erodibilitas tanah, yaitu laju erosi per indeks erosi hujan (R) untuk suatu tanah yang didapat dari petak percobaan standar, yaitu petak percobaan yang panjangnya $72,6 \mathrm{ft}(22,1 \mathrm{~m})$ dan terletak pada lereng $9 \%$ tanpa tanaman.
$\mathrm{L}$ = adalah faktor panjang lereng, yaitu perbandingan antara besarnya erosi dari tanah dengan suatu panjang lereng tertentu terhadap erosi dari tanah dengan panjang lereng $72,6 \mathrm{ft}$ $(22,1 \mathrm{~m})$ di bawah keadaan yang identik.

$\mathrm{S}=$ adalah faktor kecuraman lereng, yaitu perbandingan antara besarnya erosi yang terjadi dari suatu bidang tanah dengan kecuraman lereng tertentu, terhadap besarnya erosi dari tanah dengan lereng $9 \%$ di bawah keadaan yang identik.

$\mathrm{C}=$ adalah faktor vegetasi penutup tanah dan pengelolaan tanaman, yaitu perbandingan antara besarnya erosi dari suatu bidang tanah dengan vegetasi penutup dan pengelolaan tanaman tertentu terhadap besarnya erosi dari tanah yang identik tanpa tanaman.

$\mathrm{P}=$ adalah faktor tindakan-tindakan khusus konservasi tanah, yaitu perbandingan antara besarnya erosi dari tanah yang diberi perlakukan tindakan konservasi khusus.

Dengan memasukkan parameter-parameter R, K, LS, P dan C dalam rumus USLE, dapat diprediksi besarnya erosi tanah yang terjadi; parameter-parameter tersebut dapat diperoleh dari literatur (Kironoto dan Yulistiyanto, 2000). Besarnya erosi yang terjadi dapat memberikan gambaran tingkat erosi (kekritisan) yang terjadi pada suatu DAS, apakah dalam tingkatan yang membahayakan atau belum.

Erosivitas hujan dapat dihitung dengan ditentukan dengan persamaan Bols (1978). Sedangkan faktor erodibilitas tanah, K, adalah nilai kuantitatif yang telah didefenisikan pada pembahasan terdahulu yang dapat diperoleh dari percobaan lapangan. Jika tidak terdapat data lapangan, maka nilai $\mathrm{K}$ dapat dihitung dengan menggunakan nomogram seperti tercantum pada Gambar F.8 atau dengan mempergunakan persamaan berikut :

$$
\begin{aligned}
100 \mathrm{~K}= & 1,292[2,1 \mathrm{M} 1,14(10-4)(12-\mathrm{a})+ \\
& 3,25(\mathrm{~b}-2)+2,5(\mathrm{c}-3)]
\end{aligned}
$$

dimana 
$M$ = persentase fraksi pasir sangat halus dan fraksi debu (diameter 0,1 - 0,05 $\mathrm{mm}$ dan 0,05 -0,02 mm) $\times(100-$ persentase fraksi lempung),

$\mathrm{a}=$ persentase bahan organik,

$\mathrm{b}=$ kode struktur tanah yang dipergunakan dalam klasifikasi tanah (Tabel 1), dan

$c=$ kode klas permeabilitas profil tanah (Tabel 2).

Tabel 1: Kode Struktur tanah

\begin{tabular}{|l|c|}
\hline $\begin{array}{l}\text { Kelas Struktur Tanah } \\
\text { (Ukuran Diameter) }\end{array}$ & $\begin{array}{c}\text { Kode } \\
\text { (b) }\end{array}$ \\
\hline Granuler sangat halus (<1 mm) & 1 \\
\hline Granuler halus (1 s/ d 2 mm) & 2 \\
\hline Granuler sedang (2 s/d $10 \mathrm{~mm})$ & 3 \\
\hline Blok, blocky, plat, masif & 4 \\
\hline
\end{tabular}

Tabel 2: Kode Permeabilitas Profil tanah

\begin{tabular}{|l|c|c|}
\hline $\begin{array}{l}\text { Kelas } \\
\text { Permeabilitas }\end{array}$ & $\begin{array}{c}\text { Kecepatan } \\
\text { (cm/jam) }\end{array}$ & $\begin{array}{c}\text { Kode } \\
\text { (c) }\end{array}$ \\
\hline Sangat lambat & $<0,5$ & 6 \\
\hline Lambat & $0,5-2,0$ & 5 \\
\hline Lambat s/d sedang & $2,0-6,3$ & 4 \\
\hline Sedang & $6,3-12,7$ & 3 \\
\hline
\end{tabular}

Parameter penentu kekritisan lahan berdasarkan SK Dirjen RRL No.041 / Kpts/ V/ 1998 meliputi :

- kondisi tutupan vegetasi

- kemiringan lereng

- tingkat bahaya erosi dan singkapan batuan (outcrop), dan

- kondisi pengelolaan, produktivitas dan manajemen

Klasifikasi dari masing masing penentu dapat dilihat pada tabel 3 sampai 6 .

Penentuan lahan kritis dalam suatu DAS atau Sub DAS dilakukan dengan pemodelan spasial menggunakan perangkat lunak GIS. Metode yang digunakan untuk perolehan data ini adalah overlay dengan cara skoring untuk penentuan tingkat kekritisan suatu lahan.
Tabel 3: Klasifikasi tutupan Iahan

\begin{tabular}{|l|c|c|c|}
\hline \multicolumn{1}{|c|}{ Kelas } & $\begin{array}{c}\text { Prosentase } \\
\text { Tutupan Tajuk } \\
(\%)\end{array}$ & Skor & $\begin{array}{c}\text { Skor x Bobot } \\
(50)\end{array}$ \\
\hline \hline Sangat Baik & $>80$ & 5 & 250 \\
\hline Baik & $61-80$ & 4 & 200 \\
\hline Sedang & $41-60$ & 3 & 150 \\
\hline Buruk & $21-40$ & 2 & 100 \\
\hline Sangat Buruk & $<20$ & 1 & 50 \\
\hline
\end{tabular}

Tabel 4: Klasifikasi Kemiringan lereng

\begin{tabular}{|l|c|c|}
\hline \multicolumn{1}{|c|}{ Kelas } & $\begin{array}{c}\text { Kemiringan Lereng } \\
(\%)\end{array}$ & Skor \\
\hline \hline Datar & $<8$ & 5 \\
\hline Landai & $8-15$ & 4 \\
\hline Agak Curam & $16-25$ & 3 \\
\hline Curam & $26-40$ & 2 \\
\hline Sangat Curam & $>40$ & 1 \\
\hline \multicolumn{2}{|l}{}
\end{tabular}

Tabel 5: Klasifikasi Erosi

\begin{tabular}{|c|c|c|}
\hline Kelas & Besaran / Deskripsi & Skor \\
\hline Ringan & $\begin{array}{l}\text { Tanah dalam: } \\
<25 \% \text { lapisan tanah atas hilang } \\
\text { dan/atau erosi alur pada jarak } 20-50 \\
\mathrm{~m} \\
\text { Tanah dangkal: } \\
<25 \% \text { lapisan tanah atas hilang } \\
\text { dan/atau erosi alur pada jarak }>50 \mathrm{~m}\end{array}$ & 5 \\
\hline Sedang & $\begin{array}{l}\text { Tanah dalam } \\
25-75 \% \text { lapisan tanah atas hilang } \\
\text { dan/atau erosi alur pada jarak kurang } \\
\text { dari } 20 \mathrm{~m} \\
\text { Tanah dangkal } \\
25-50 \% \text { lapisan tanah atas hilang } \\
\text { dan/atau erosi alur dengan jarak } 20 \text { - } \\
50 \mathrm{~m}\end{array}$ & 4 \\
\hline Berat & $\begin{array}{l}\text { Tanah dalam } \\
\text { Lebih dari } 75 \% \text { lapisan tanah atas } \\
\text { hilang dan/atau erosi parit dengan } \\
\text { jarak } 20-50 \mathrm{~m} \\
\text { Tanah dangkal } \\
50-75 \% \text { lapisan tanah atas hilang }\end{array}$ & 3 \\
\hline Sangat Berat & $\begin{array}{l}\text { Tanah dalam } \\
\text { Semua lapisan tanah atas hilang >25 } \\
\% \text { lapisan tanah bawah dan/atau erosi } \\
\text { parit dengan kedalaman sedang pada } \\
\text { jarak kurang dari } 20 \mathrm{~m} \\
\text { Tanah dangkal } \\
>75 \% \text { lapisan tanah atas telah hilang, } \\
\text { sebagian lapisan tanah bawah telah } \\
\text { tererosi }\end{array}$ & 2 \\
\hline
\end{tabular}


Tabel 6: Klasifikasi Produktivitas

\begin{tabular}{|l|l|c|c|}
\hline \hline Kelas & \multicolumn{1}{|c|}{ Besaran / Deskripsi } & Skor & $\begin{array}{c}\text { Skor } \times \text { Bobot } \\
(30)\end{array}$ \\
\hline \hline $\begin{array}{l}\text { Sangat } \\
\text { Tinggi }\end{array}$ & $\begin{array}{l}\text { ratio terhadap produksi } \\
\text { komoditi umum optimal } \\
\text { pada pengelolaan } \\
\text { tradisional : }>80 \%\end{array}$ & 5 & 150 \\
\hline Sedang & $\begin{array}{l}\text { ratio terhadap produksi } \\
\text { komoditi umum optimal } \\
\text { pada pengelolaan } \\
\text { tradisional : } 61-80^{*}\end{array}$ & 4 & 120 \\
\hline Rendah & $\begin{array}{l}\text { ratio terhadap produksi } \\
\text { komoditi umum optimal } \\
\text { pada pengelolaan } \\
\text { tradisional : } 41-60 \%\end{array}$ & 3 & 90 \\
\hline $\begin{array}{l}\text { ratio terhadap produksi } \\
\text { komoditi umum optimal } \\
\text { pada pengelolaan } \\
\text { tradisional }: 21-40 \%\end{array}$ & 2 & 60 \\
\hline $\begin{array}{l}\text { Sangat } \\
\text { Rendah }\end{array}$ & $\begin{array}{l}\text { ratio terhadap produksi } \\
\text { komoditi umum optimal } \\
\text { pada pengelolaan } \\
\text { tradisional }:<20 \%\end{array}$ & 1 & 30 \\
\hline
\end{tabular}

\section{HASIL DAN PEMBAHASAN}

\subsection{Konstruksi DEM dan aplikasinya}

Konstruksi DEM (Digital Elevation Model) yang disediakan pada beberapa modul di berbagai perangkat lunak GIS pada dasarnya menggunakan formula matematis yang hampir sama. Metode yang paling umum digunakan adalah metode linear gridding yaitu cara untuk menginterpolasi data ketinggian (baik berupa garis maupun titik ) kemudian dikonversi menjadi format raster yang hasil akhirnya berupa piksel atau cell grid.

Data DEM merupakan data spasial yang berisi nilai ketinggian, dari data DEM ini dapat diekstraksi menjadi beberapa turunan data spasial lain seperti contour reconditioning. Data DEM yang dihasilkan pada penelitian ini dihasilkan dari data kontur digital RBI skala 1:25,000 yang memiliki interval $12,5 \mathrm{~m}$. Pembangunan data ini dilakukan dengan menggunakan ArcView 3.2 (ekstensi spatial analyis 2.0). Model seperti ini sudah banyak dikembangkan pada perangkat lunak pengolah data GIS lainnya. Data DEM SRTM yang dapat diperoleh secara gratis melalui akses internet ke NASA memiliki resolusi $90 \mathrm{~m}$. Hasil pengukuran ketelitian akurasi vertikal untuk data DEM SRTM ini menunjukkan kesalahan sekitar 18$25 \mathrm{~m}$, sedangkan pada data kontur RBI skala
1:25,000 dari BAKOSURTANAL, kesalahan vertikalnya $<5 \mathrm{~m}$, sehingga DEM yang digunakan untuk analisis adalah DEM yang dikontruksi dari data RBI digital 1:25,000. Hasil pengolahan DEM ini dapat dilihat pada gambar 2 berikut,

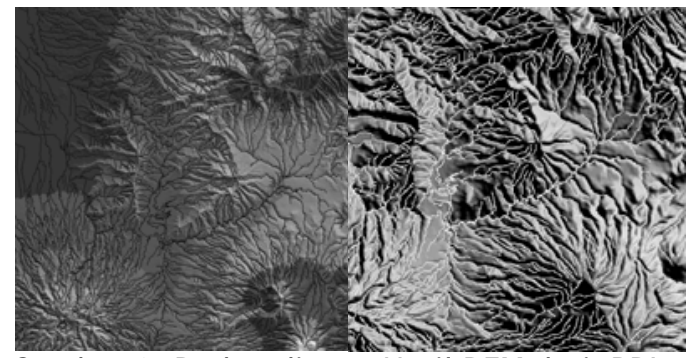

Gambar 2: Perbandingan Hasil DEM dari RBI 1:25.000 (kiri) dan dari SRTM resolusi $90 \mathrm{~m}$ (kanan)

\subsection{Ekstraksi Data Kemiringan Lereng}

Seperti telah dijelaskan pada bagian metodologi bahwa data lereng yang dihasilkan pada kegiatan ini merupakan suatu produk dari aplikasi otomatis perangkat lunak GIS ArcView 3.2 melalui fasilitas ekstensi Spatial Analysis. Kelebihan utama dari tools ini adalah pengguna dapat menentukan klas lereng secara fleksibel sesuai peruntukannya. Hal ini dikarenakan format data yang digunakan sebagai bahan analisa adalah format grid (sel raster). Nantinya data ini harus dikonversi kembali ke format vektor agar dapat dianalisa bersamaan dengan data-data (pemodelan spasial).

Klas kemiringan lereng yang digunakan dalam penelitian ini terdiri dari 5 klas tetapi guna mempertajam analisa kawasan selanj utnya maka klas lereng dikelompokkan menjadi 6 klas yaitu Klas I-datar (0-3ㅇ), Klas II-landai (3-8o), Klas III-bergelombang (8150), Klas IV-agak curam (15-250), Klas Vcuram (25-40), dan Klas VI-sangat curam $(>40$ ) .

Hasil analisa kemiringan lereng untuk areal Sub DAS Riam Kanan tersaji dalam tabel 7 berikut: 
Tabel 7: Hasil analisa kemiringan lereng

\begin{tabular}{|c|c|c|c|c|}
\hline No. & Kelas & $\begin{array}{c}\text { Keminingan } \\
\text { (\%) }\end{array}$ & $\begin{array}{c}\text { Luas } \\
\left(\mathbf{k m}^{\mathbf{}} \mathbf{)}\right.\end{array}$ & Prosentase \\
\hline \hline 1 & $\mathrm{I}$ & $0-3$ & 575.3931 & 49.69 \\
\hline 2 & $\mathrm{II}$ & $3-8$ & 130.3448 & 11.26 \\
\hline 3 & $\mathrm{III}$ & $8-15$ & 199.8813 & 17.26 \\
\hline 4 & $\mathrm{IV}$ & $15-25$ & 5.2907 & 0.46 \\
\hline 5 & $\mathrm{~V}$ & $25-45$ & 169.0990 & 14.60 \\
\hline 6 & $\mathrm{VI}$ & $>45$ & 77.9512 & 6.73 \\
\hline \multicolumn{6}{|c|}{ Total } & 1157.9600 & 100.00 \\
\hline
\end{tabular}

\subsection{Ekstraksi Data Tutupan Lahan}

Ekstraksi data tutupan Iahan ini sepenuhnya bertumpu pada interpretasi visual citra ASTER. Data spasial yang digunakan sevagai bahan analisa adalah data citra satelit ASTER perekaman tahun 2007

Untuk menghasilkan komposit warna asli (true color) pada citra ASTER dilakukan operasi matematis dengan menerapkan formulasi RGB: band2, (3 $x$ band1 + band3) / 4 , band1 yang hasilnya seperti tampak pada gambar 3 dan hasil selengkapnya dapat dilihat pada gambar 4. Berdasarkan hasil liputan citra ini dapat dihitung luas masing masing jenis tutupan lahan seperti ditunjukkan pada tabel 8.

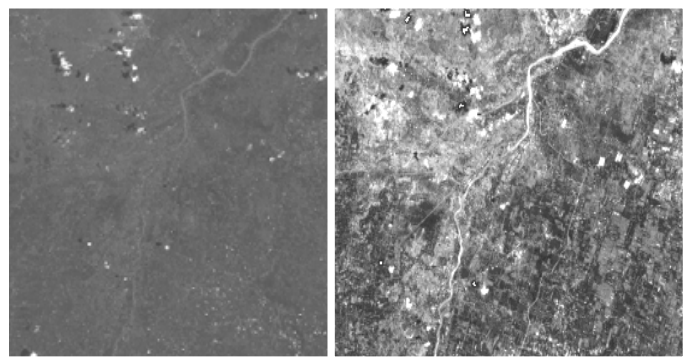

Gambar 3: Kenampakan citra ASTER RGB 321

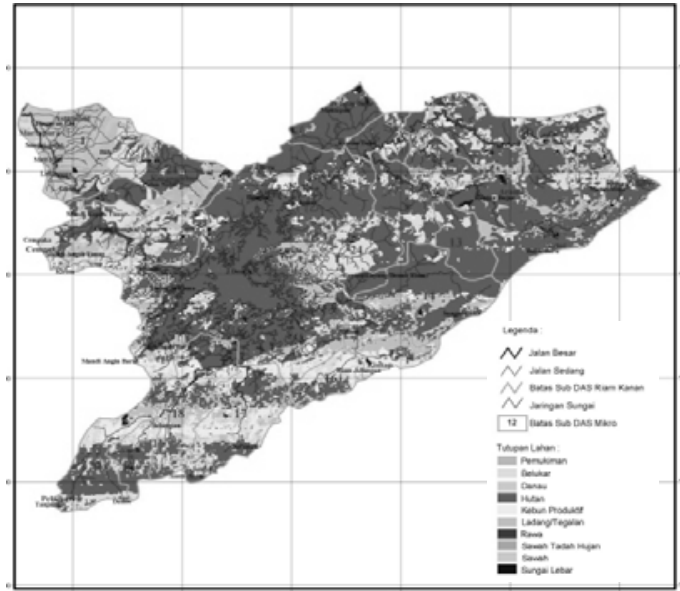

Gambar 4. Tutupan Iahan hasil liputan Citra ASTER
Tabel 8. Luas tutupan lahan dari citra aster 2008

\begin{tabular}{|c|c|c|c|}
\hline No. & Jenis Tutupan Lahan & $\begin{array}{c}\text { Las } \\
\left(\mathbf{k m} \mathbf{c}^{\mathbf{}}\right.\end{array}$ & Prosentase \\
\hline \hline 1 & Belukar & 206.9647 & 17.873 \\
\hline 2 & Danau & 46.5316 & 4.018 \\
\hline 3 & Hutan & 509.9396 & 44.038 \\
\hline 4 & Kebun Produktif & 114.9329 & 9.925 \\
\hline 5 & Ladang/Tegalan & 162.5119 & 14.034 \\
\hline 6 & Pemukiman & 43.1860 & 3.729 \\
\hline 7 & Rawa & 0.0953 & 0.008 \\
\hline 8 & Sawah Tadah Hujan & 0.2554 & 0.022 \\
\hline 9 & Sawah & 64.8900 & 5.604 \\
\hline 10 & Sungai Lebar & 8.6524 & 0.747 \\
\hline \multicolumn{3}{|c|}{} \\
\hline
\end{tabular}

Jika luas tutupan lahan tahun 2008 ini dibandingkan dengan luas tutupan lahan pada tahun 2006 yang dihasilkan dari olahan peta RBI (tabel.9) hanya ada sedikit perubahan.

Tabel 9. Luas tutupan Iahan tahun 2006

\begin{tabular}{|c|c|c|c|}
\hline No. & Jenis Tutupan Lahan & $\begin{array}{c}\text { Luas } \\
\left(\mathrm{km}^{2}\right)\end{array}$ & Prosentase \\
\hline$\overline{11}$ & Belukar & 207.7872 & 17.944 \\
\hline 2 & Danau & 46.7719 & 4.039 \\
\hline 3 & Hutan & 509.5131 & 44.001 \\
\hline 4 & Kebun & 118.5519 & 10.238 \\
\hline 5 & Ladang/Tegalan & 163.4670 & 14.117 \\
\hline 6 & Pemukiman & 31.0015 & 2.677 \\
\hline 7 & Rawa & 0.0954 & 0.008 \\
\hline 8 & Sawah Tadah Hujan & 0.2557 & 0.022 \\
\hline 9 & Sawah & 74.3172 & 6.418 \\
\hline 10 & Sungai Lebar & 6.0562 & 0.523 \\
\hline & Total & 1157.9600 & 100.000 \\
\hline
\end{tabular}

\subsection{Daerah Tangkapan Air (DTA)}

Pengolahan DEM-DTM digunakan untuk mendapatkan peta kontur dalam format grid dari peta topografi digital dengan skala 1:25.000. Kemudian dari DEM dalam format grid tersebut akan didapatkan peta jaringan sungai sintetik. Setelah peta jaringan sungai sintetik terbentuk maka dapat digunakan dalam penentuan peta batasan DAS (model DAS). Dengan pemodelan batasan DAS beserta jaringan sungai sintetiknya, maka akan didapatkan karakteristik fisik daerah yang berupa arah aliran (flow direction), panjang aliran (flow lenght) dari upstream DAS sampai outlet, dan kemiringan lereng (slope). Dengan kata lain dari proses DEMDTM juga untuk penentuan faktor panjang dan kemiringan lereng (LS) yang nantinya digunakan dalam penentuan besarnya laju erosi.

Hasil analisa ini menunjukkan bahwa Sub DAS Riam Kanan yang luasnya 1.157,96 Km2 terbagi menjadi 27 Sub DAS Mikro. Gambar 5 menunjukkan pembagian sub DAS mikro 
Riam Kanan dan tabel 10 menunjukkan luas masing masing sub DAS Mikro tersebut.

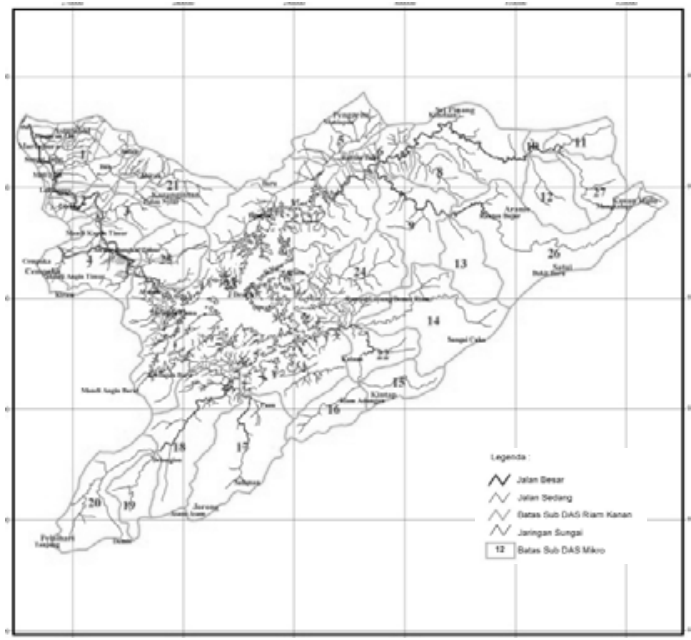

Gambar 5: Pembagian Sub DAS Miro

Tabel 10: Luas Sub DAS Mikro Riam Kanan

\begin{tabular}{|c|c|c|c|c|c|}
\hline No & $\begin{array}{l}\text { Luas } \\
(\mathrm{Km} 2)\end{array}$ & No & $\begin{array}{l}\text { Luas } \\
(\mathrm{Km} 2)\end{array}$ & No & Luas (Km2) \\
\hline 1 & 49.08 & 10 & 5.57 & 19 & 18.74 \\
\hline 2 & 15.51 & 11 & 15.34 & 20 & 40.10 \\
\hline 3 & 15.39 & 12 & 26.18 & 21 & 40.38 \\
\hline 4 & 45.16 & 13 & 25.74 & 22 & 29.30 \\
\hline 5 & 26.95 & 14 & 58.42 & 23 & 281.53 \\
\hline 6 & 18.60 & 15 & 17.81 & 24 & 37.30 \\
\hline 7 & 46.50 & 16 & 21.26 & 25 & 42.76 \\
\hline 8 & 19.13 & 17 & 56.84 & 26 & 85.04 \\
\hline 9 & 39.85 & 18 & 57.84 & 27 & 21.64 \\
\hline \multicolumn{5}{|c|}{ Luas Total DAS } & $1,157.96$ \\
\hline
\end{tabular}

\subsection{Kemiringan Lereng}

Klas kemiringan lereng yang digunakan dalam penelitian ini terdiri dari 5 klas tetapi guna mempertajam analisa kawasan selanjutnya maka klas lereng yang dibagi menjadi 6 klas yaitu Klas I-datar (0-30), Klas II-Iandai (3-80), Klas III-bergelombang (8150), Klas IV-agak curam (15-250), Klas Vcuram (25-40), dan Klas VI-sangat curam $\left(>40^{\circ}\right)$.

Hasil analisa kemiringan lereng untuk areal Sub DAS Riam Kanan tersaji dalam tabel 11 dan gambar 6 berikut:
Tabel 11: Kemiringan lereng

\begin{tabular}{|c|c|c|c|c|}
\hline No. & Kelas & $\begin{array}{c}\text { Keminingan } \\
\text { (\%) }\end{array}$ & $\begin{array}{c}\text { Luas } \\
\left(\mathbf{k m}^{2}\right)\end{array}$ & Prosentase \\
\hline$\overline{11}$ & $T$ & $0-3$ & $\overline{575.3931}$ & 49.69 \\
\hline 2 & II & $3-8$ & 130.3448 & 11.26 \\
\hline 3 & III & $8-15$ & 199.8813 & 17.26 \\
\hline 4 & IV & $15-25$ & 5.2907 & 0.46 \\
\hline 5 & V & $25-45$ & 169.0990 & 14.60 \\
\hline 6 & VI & $>45$ & 77.9512 & 6.73 \\
\hline \multicolumn{3}{|c|}{ Total } & 1157.9600 & 100.00 \\
\hline
\end{tabular}

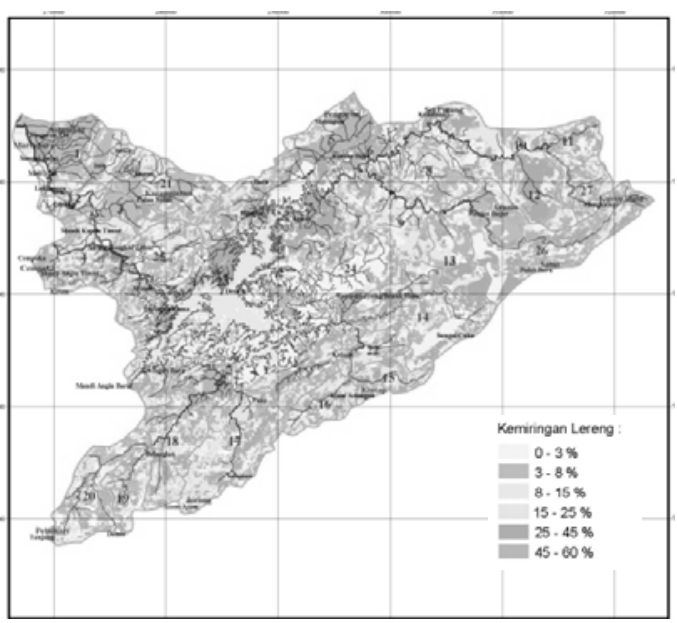

Gambar 6: Pembagian kemiringan lereng

\subsection{Indeks Erosivitas}

Indeks erosivitas hujan (R) didefinisikan sebagai jumlah satuan indeks erosi hujan dalam setahun. Nilai R yang merupakan daya rusak hujan, dapat ditentukan dengan persamaan Bols (1978) dalam Suripin (2002:72)

$$
E I_{30}=6,119 P_{b}^{1,211} \cdot N^{-0.474} \cdot P_{\max }^{0,526}
$$

dengan :

$\mathrm{EI30}=$ Indeks erosi hujan bulanan (KJ / ha)

$\mathrm{Pb}=$ Curah hujan bulanan $(\mathrm{cm})$

$\mathrm{N}=$ Jumlah hari hujan per bulan

Pmax = Hujan maksimum harian (24 jam) dalam bulan yang bersangkutan (cm)

Tabel 12: Erosivitas lahan 15 tahun terakhir

\begin{tabular}{|c|c|c|c|c|c|}
\hline Tahun & Erosivitas & Tahun & Erosivitas & Tahun & Erosivitas \\
\hline 1992 & $1,761.00$ & 1997 & $1,242.68$ & 2002 & $1,132.95$ \\
\hline 1993 & $3,089.67$ & 1998 & $1,559.52$ & 2003 & $4,131.17$ \\
\hline 1994 & $1,345.33$ & 1999 & $1,070.33$ & 2004 & $2,172.82$ \\
\hline 1995 & $1,874.74$ & 2000 & $1,441.14$ & 2005 & $2,130.19$ \\
\hline 1996 & $1,310.23$ & 2001 & 356.23 & 2006 & $1,562.40$ \\
\hline \multicolumn{5}{|c|}{ Total Indeks Erosivitas } & $26,180.40$ \\
\hline \multicolumn{5}{|c|}{ Rata rata } & $1,745.36$ \\
\hline
\end{tabular}




\subsection{Indeks Erodibilitas Tanah (K)}

Penentuan nilai indeks erodibilitas tanah (K) terhadap jenis tanah dilakukan dengan menggunakan peta jenis tanah dari Dinas Kehutanan seperti terlihat pada Gambar 7.

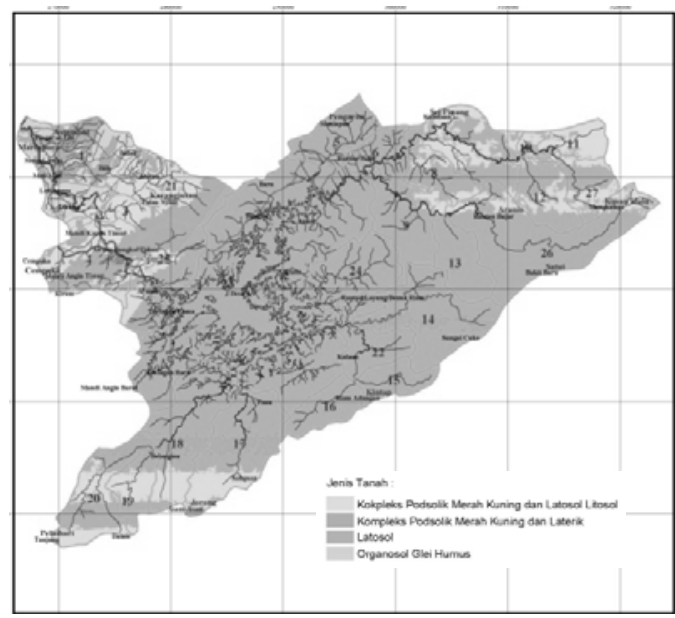

Gambar 7: Erodibilatas Lahan

\subsection{Tingkat Bahaya Erosi (TBE)}

Tingkat bahaya erosi merupakan suatu perkiraan jumlah tanah hilang maksimum yang akan terjadi pada sebidang lahan. Dalam pelaksanaan program konservasi tanah salah satu informasi penting yang harus diketahui adalah tingkat bahaya erosi (TBE). Penentuan TBE, menggunakan pendekatan tebal solum tanah ( Dirjen RLKT Departemen Kehutanan. Makin dangkal solum tanahnya, berarti makin sedikit tanahnya yang tererosi, sehingga TBEnya sudah cukup besar meskipun tanah yang hilang belum terlalu besar (Hardjowigeno, 2003: 203). Pada Tabel 12. disajikan penilaian TBE berdasarkan atas tebal solum tanah dan besarnya laju erosi. Berdasarkan analisa tingkat bahaya erosi (TBE) tersebut, dapat diketahui bahwa 19.862 \%lahan di sub DAS Riam Kanan mengalami tingkat bahaya erosi yang sangat berat.
Tabel 12: Tingkat Bahaya Erosi

\begin{tabular}{|c|c|c|c|}
\hline No. & TBE & $\begin{array}{c}\text { Luas } \\
\left(\mathbf{k m}^{\mathbf{}} \mathbf{)}\right.\end{array}$ & Prosentase \\
\hline \hline 1 & Sangat Ringan & 79.730 & 6.885 \\
2 & Ringan & 245.684 & 21.217 \\
3 & Sedang & 174.240 & 15.047 \\
4 & Berat & 381.069 & 32.909 \\
5 & Sangat Berat & 229.995 & 19.862 \\
6 & No TBE & 47.243 & 4.080 \\
\hline \multicolumn{3}{|c|}{} \\
\hline
\end{tabular}

\subsection{Kekritisan Lahan dan Laju Erosi}

Kekritisan lahan adalah suatu lahan yang keadaan fisiknya sedemikian rupa sehingga lahan tersebut tidak dapat berfungsi secara baik sesuai dengan peruntukannya baik sebagai media produksi maupun sebagai media tata air. Lahan yang tergolong kritis tersebut dapat berupa: (a) tanah gundul yang tidak bervegetasi sama sekali; (b) ladang alang-alang atau tanah yang ditumbuhi semak belukar yang tidak produktif; (c) areal berbatu-batu, berjurang atau berparit sebagai akibat erosi tanah; (d) tanah yang kedalaman solumnya sudah tipis sehingga tanaman tidak dapat tumbuh dengan baik; (e) tanah yang tingkat erosinya melebihi erosi yang diijinkan. Tabel 13 menunjukkan sebaran kekritisan lahan di Sub DAS Riam Kanan, dari tabel ini terlihat bahwa lahan kritis pada daerah ini lebih dari $43 \%$ atau dapat dikatakan bahwa hampir setengah Iahan sub DAS Riam telah menjadi kritis.

Tabel 14 menunjukkan total dan laju erosi pada setiuap sub DAS Mikro, dari tabel ini terlihat bahwa ada beberapa sub Das Mikro yang memiliki laju erosi yang sangat tinggi yaitu sub DAS mikro 27, 4, 26.

Tabel 13: Keritisan Lahan Sub DAS Riam Kanan

\begin{tabular}{|c|c|c|c|}
\hline No. & Kekritisan & $\begin{array}{c}\text { Luas } \\
\left(\mathbf{k m}^{\mathbf{2}}\right)\end{array}$ & Prosentase \\
\hline \hline 1 & Potensial Kritis & 325.413 & 28.102 \\
2 & Semi Kritis & 300.529 & 25.953 \\
3 & Kritis & 308.728 & 26.661 \\
4 & Sangat Kritis & 176.046 & 15.203 \\
5 & Tidak Kritis & 47.243 & 4.080 \\
\hline \multicolumn{2}{|l|}{} \\
\hline
\end{tabular}


Tabel 14: Total erosi disetiap Sub DAS Mikro

\begin{tabular}{|c|c|c|c|}
\hline No & Luas (Km2) & $\begin{array}{c}\text { Erosi } \\
\text { (ton/th) }\end{array}$ & $\begin{array}{l}\text { Laju Erosi } \\
\text { (mm/th) }\end{array}$ \\
\hline 1 & 49.08 & $183,081.63$ & 2.33 \\
\hline 2 & 15.51 & $128,131.84$ & 5.16 \\
\hline 3 & 15.39 & $332,985.61$ & 13.52 \\
\hline 4 & 45.16 & $2,316,617.80$ & 32.06 \\
\hline 5 & 26.95 & $132,571.86$ & 3.07 \\
\hline 6 & 18.60 & $25,701.73$ & 0.86 \\
\hline 7 & 46.50 & $1,020,299.47$ & 13.71 \\
\hline 8 & 19.13 & $288,177.41$ & 9.42 \\
\hline 9 & 39.85 & $322,060.06$ & 5.05 \\
\hline 10 & 5.57 & $170,509.16$ & 19.13 \\
\hline 11 & 15.34 & $266,504.92$ & 10.86 \\
\hline 12 & 26.18 & $599,013.20$ & 14.30 \\
\hline 13 & 25.74 & $76,748.76$ & 1.86 \\
\hline 14 & 58.42 & $422,830.55$ & 4.52 \\
\hline 15 & 17.81 & $126,109.27$ & 4.43 \\
\hline 16 & 21.26 & $284,922.10$ & 8.38 \\
\hline 17 & 56.84 & $389,710.53$ & 4.29 \\
\hline 18 & 57.84 & $664,906.54$ & 7.18 \\
\hline 19 & 18.74 & $184,828.91$ & $\overline{6.16}$ \\
\hline 20 & 40.10 & $364,217.84$ & 5.68 \\
\hline 21 & 40.38 & $1,042,689.09$ & 16.14 \\
\hline 22 & 29.30 & $132,066.60$ & 2.82 \\
\hline 23 & 281.53 & $932,597.97$ & 2.07 \\
\hline 24 & 37.30 & $62,544.70$ & 1.05 \\
\hline 25 & 42.76 & $1,361,700.69$ & 19.90 \\
\hline 26 & 85.04 & $4,288,764.86$ & 31.52 \\
\hline 27 & 21.64 & $1,357,085.69$ & 39.19 \\
\hline \multicolumn{2}{|r|}{ Total } & $17,477,378.79$ & 284.68 \\
\hline
\end{tabular}

\subsection{Rencana Upaya Tindak Lanjut}

Berdasarkan uraian uraian dimuka terutama tentang tingkat laju Erosi, maka pada Sub DAS Riam Kanan perlu dikelompokkan menjadi 3 tahap penanganan yaitu jangka pendek, menengah, dan panjang. Tabel 15 menunjukkan pembagian Sub DAS Mikro yang harus ditindak lanjuti sesuai dengan jangka waktu masing masing.

Untuk menetapkan urutan prioritas tentunya diperlukan kajian lebih lanjut yang menyangkut tentang dampak yang ditimbulkan. Sebesar apapun erosi / yang terjadi tetapi jika tidak berdampak pada lingkungan termasuk sosial masyarakat maka prioritas penanganan menjadi urutan terakhir.
Tabel 15: J angka waktu upaya tindak Lanjut.

\begin{tabular}{|l|c|c|c|c|c|c|c|c|c|c|c|}
\hline J angka lanjutan & \multicolumn{10}{|c|}{ Nomer Sub DAS Mikro Riam Kanan } \\
\hline Pendek & 3 & 4 & 7 & 10 & 11 & 12 & 21 & 25 & 26 & 27 & \\
\hline Menengah & 2 & 5 & 8 & 9 & 14 & 15 & 16 & 17 & 18 & 19 & 20 \\
\hline Panjang & 1 & 6 & 13 & 22 & 23 & 24 & & & & & \\
\hline
\end{tabular}

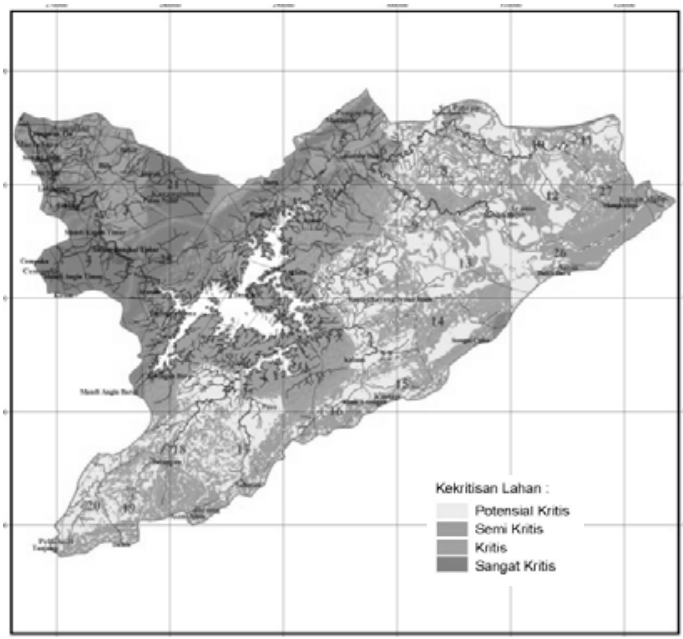

Gambar 8: Tingkat Kekritisan Lahan

\section{KESIMPULAN}

Berdasarkan analisa analisa yang telah dilakukan maka kekritisan Iahan Sub DAS Riam Kanan dapat disimpulkan sebagai berikut :

- Erosi pada Sub DAS Riam Kanan sebesar 150,9322 ton/ Ha/tahun dengan laju erosi rata rata sebesar $9,43 \mathrm{~mm} /$ thn.

- Hampir 50\% lahan pada Sub DAS Riam Kanan merupakan daerah kritis yang terbagai menjadi 2 yaitu sangat kritis $(176,046 \mathrm{Ha})$ dan kritis $(308,728 \mathrm{Ha})$.

- Agar sub DAS Riam Kanan tidak menjadi lebih parah maka harus ditangai secara bertahap, 30\% harus ditangani pada jangka pendek, $32 \%$ masuk dalam menengah dan 38\% cukup ditangani pada jangka panjang.

- Untuk menetapkan prioritas dan cara penanganan perlu dikaji lebih lanjut tentang dampak yang ditimbulkan di masing masing sud Das Mikro. 


\section{DAFTAR ACUAN}

Puser Bumi, PT ( 2008 ), Laporan Sela Studi Konservasi Sub DAS Riam Kanan, Balai Wilayah Sungai Kalimantan II Dirjen SDA Dep. PU.

Kirkby, MJ (1980), Soil Erosian, J ohn Wiley \& Sons. Ltd, Chichiester.

Dent, D and Young, A (1981), Soil Survey and Land Evaluation, George Allen \& Unwin, London.

Ananto Kusuma Seta (1987), Konservasi sumber daya Tanah dan Air, Kalam Mulia, J akarta

Kartasaputro (2000), Teknologi Konservasi Tanah \& Air, Rineka Cipta, J akarta 